ISSN 0258-7122 (Print), 2408-8293 (Online)

Bangladesh J. Agril. Res. 41(3): 521-528, September 2016

\title{
ORGANOGENESIS IN OKRA (Abelmoschus esculentus L. Moench.): A PLANT RECALCITRANT TO TISSUE CULTURE
}

\author{
M. R. KABIR ${ }^{1}$, S. AHMED ${ }^{2}$ AND M. A. Y. AKHOND ${ }^{3}$
}

\begin{abstract}
Seedling-derived cotyledonary nodes and hypocotyl explants of BARI Dherosh1 were cultured in vitro on MS medium supplemented with varying concentrations of 2, 4-Dichlorophenoxy acetic acid (2, 4-D), 6Benzylaminopurine (BAP), Thidiazuron (TDZ), BAP with 1-Nepthaleneacetic acid (NAA), BAP with Indole 3-butyric acid (IAA) and Zeatin with IAA along with a control. Shooting response $(100 \%)$ with callus was only observed from cotyledonary nodes on thidiazuron (TDZ) where hypocotyls produced only callus or callus with roots on different concentrations of plant growth regulators. Considering the shooting response, the cotyledonary nodes of BARI Dherosh-1 were cultured on various concentrations of TDZ for regeneration. The highest percentage (64.0) with maximum number (6.8) of shoots per explant were observed in $0.044 \mu \mathrm{M}$ TDZ in 8.4 days. The regenerated shoots were rooted on $1 / 2$ strength MS, MS supplemented with $2.46 \mu \mathrm{M}$ IBA and $0.53 \mu \mathrm{M}$ NAA. The highest percentage (83.3) and minimum days (9.7) required for root induction were recorded in $2.46 \mu \mathrm{M}$ IBA. The rooted plantlets were transferred to soil and hardened in the plastic pots under green house conditions. The rooted shoots grew normally under natural conditions following acclimatization.
\end{abstract}

Keywords: Abelmoschus esculentus, cotyledonary node, TDZ, IBA.

\section{Introduction}

Okra (Abelmoschus esculentus L Moench.) is cultivated in tropical, subtropical and warm temperate regions around the world including Bangladesh. It belongs to the Malvaceae family and is known by many local names in different parts of the world. It is called lady's finger outside of the United States, gumbo in parts of the United States and English-speaking Caribbean and in Southern Asia, its name is usually a variant of bhindi or vendi. It is a good source of protein, vitamin C and A, iron, calcium (Aworh et al. 1980; Ihekoronye and Ngoddy 1985) and dietary fiber (Adom et al., 1996). It is known as powerhouse of valuable nutrients having low calories and is fat-free. Its ripe seeds are roasted, ground and used as a substitute of coffee in some countries. Extracts from the seeds of okra is viewed as alternative source for edible oil. The oil content of the seed is high at about $40 \%$. Therefore, considerable attention should be given for the improvement of this vegetable.

${ }^{1,2 \& 3}$ Biotechnology Division, Bangladesh Agricultural Research Institute (BARI), Gazipur-1701, Bangladesh. 
In 2012-13, okra production was 44.0 thousand metric tons from 10.66 thousand hectors of land in Bangladesh (BBS, 2015). Despite of its importance, the production of okra is very low in Bangladesh compared to other countries in the world because it is frequently infected by a number of systemic diseases caused by fungi, viruses, bacteria, mycoplasma and nematodes. Among of them Yellow Vein Mosaic Virus (YVMV) transmitted by whitefly (Bemisia tabaci) is the most serious disease of okra. It may reduce the production up to $90 \%$ (Pullaiah et al., 1998; Kucharek, 2004). Vectors usually attack the young okra plants at the vegetative stage for virus transmission. Frequent use of pesticides by the farmers, without recognizing the vector(s) may create toxic residues in the food chain. Recognizing its economic importance there is a massive scope of utilizing modern biotechnology for further improvement of okra, because conventional plant breeding methods are difficult and time consuming. Therefore, genetic transformation technology could be used to overcome this problem; hence a regeneration protocol is prerequisite (Mitra, 2011). But a very few number of regeneration protocol has been reported to date (Dhande et al., 2012; Ganesan et al., 2007; Haider et al., 1993) probably due to low percentage of regeneration, excretion of mucilage and phenolic compounds from explants to medium and browning of callus. Therefore, the present research was undertaken to develop a simple and efficient regeneration protocol of okra aiming at future genetic transformation.

\section{Materials and Method}

Plant materials, explants sterilization and culture conditions: BARI Dherosh 1 seeds were collected from Horticulture Research Centre, Bangladesh Agricultural Research Institute, Gazipur. Clean and healthy seeds were washed with $100 \%$ ethanol and sterilized for 20 minutes in $1 \%(\mathrm{v} / \mathrm{v})$ sodium hypochlorite containing 3-4 drops Tween 20 in a laminar air flow cabinet. Afterwards, they were rinsed 4 times with sterile distilled water and transferred to $1 / 2$ strength MS medium (Murashige and Skoog, 1962) supplemented with $30 \mathrm{~g} / \mathrm{L}$ sucrose, vitamins and $8.5 \mathrm{~g} / \mathrm{L}$ agar and kept at dark condition. The $\mathrm{pH}$ of the medium was adjusted to 5.8 before autoclaving at $121^{\circ} \mathrm{C}, 15 \mathrm{psi}$ for $20 \mathrm{~min}$. Seeds started to germinate after 2-3 days and transferred to growth chamber maintained at $24 \pm 2^{\circ} \mathrm{C}$ under a $16 / 8$-h (light/dark) photoperiod.

Regeneration: Cotyledonary nodes and hypocotyls of seedlings were carefully excised and cultured on MS medium supplemented with varying concentrations of 2,4-D (2.26, 4.52, 6.78 and $9.04 \mu \mathrm{M})$, BAP $(2.22,4.44,6.66$ and $8.88 \mu \mathrm{M})$, TDZ $(0.022,0.044,0.22,0.45$ and $2.25 \mu \mathrm{M})$, BAP and NAA in combinations $(4.44+0.53,8.88+0.53 \mu \mathrm{M}), \mathrm{BAP}$ and IAA in combinations $(4.44+0.57$, $8.88+0.57 \mu \mathrm{M})$, Zeatin and IAA in combinations $(4.56+0.57,9.12+0.57 \mu \mathrm{M})$ along with a control treatment without any growth regulators. Based on the 
response of two different types of explants the cotyledonary nodes were cultured on media having five different concentrations of TDZ for further regeneration. Four explants were placed on each petridish $(15$ X $90 \mathrm{~mm})$ containing about 30 $\mathrm{ml}$ medium. The petridishes were sealed with parafilm and kept at $24 \pm 2^{\circ} \mathrm{C}$ under a 16/8-h (day/night) photoperiod with a light intensity 1500 lux. Explants were subcultured in every 14 days on the same media and kept under same conditions. When shoots attained a height of 2.0-2.5 cm they were cleaned, excised and transferred to $1 / 2$ strength of MS, MS supplemented with $2.46 \mu \mathrm{M}$ IBA and 0.53 $\mu \mathrm{M}$ NAA for root induction.

Acclimatization: Well developed rooted shoots were transferred to pots with sterile soil mix and enclosed with polythene bags to maintain high humidity. The plantlets were kept in the greenhouse and watered once or twice a week while keeping covered. After 2 weeks, the bags were removed and the plantlets were transferred to the field for growing to maturity.

Data analysis: The experiment was set up in a completely randomized design with three independent replicates. The analysis of variance for different parameters was performed and the means were compared by $\mathrm{R}$ programme using STAR software at $5 \%$ level of significance.

\section{Results and discussion}

Shoot induction: Cotyledonary nodes and hypocotyl explants of 10-12 day old in vitro grown seedlings (Fig.1a) were cultured on MS medium containing varying concentrations and combinations of plant growth regulators. Callus with shoots was only obtained from cotyledonary nodes where hypocotyl explants did not produce any shoots (Table 1). Mangat and Roy (1986) also observed shoot induction from cotyledon and cotyledonary node explants of okra cultured in a medium supplemented with benzyladenine and NAA. In another study, cotyledonary node $(\mathrm{CN})$ explants showed the best response with regard to induction of multiple shoots among various explants used for morphogenesis of Abelmoschus moschatus Medik. L. (Sharma and Shahzad, 2008).

The cotyledonary node explants showed better shooting response than hypocotyls and hence, they were further cultured on five different concentrations of TDZ for regeneration (Table 2). During every subculture, dead and brown portions of calli were removed and only the greenish parts were transferred for further proliferation. The results showed that the highest percentage $(64.0 \%)$ of shooting and minimum days (8.4) required for shoot induction were observed in MS medium supplemented with $0.044 \mu \mathrm{M}$ TDZ which is statistically different from treatments with other concentrations of TDZ (Table 2 and Fig.1b). Previously, it was observed that the biological activity of TDZ is higher than, or compatible to that, of the most active adenine type cytokinins (Mok et al., 2007; Khawar et al., 
2004). In contrast, Anisuzzaman et al. (2008) found $95 \%$ callogenic response from hypocotyl explants of okra and 65\% callus produced shoots over a period of 7 weeks in the MS medium containing $8.88 \mu \mathrm{M}$ BAP plus $0.5 \mu \mathrm{M}$ IBA which differ from the present study. The highest number of shoots (6.8) per explant was also recorded from MS medium supplemented with $0.044 \mu \mathrm{M}$ TDZ followed by $0.022 \mu \mathrm{M}$ (4.3) and the shoot multiplication did not rise with further increase in the concentrations of TDZ (Table 2 and Fig. 1c). The concentration of TDZ used for tissue culture is generally lower than that normally used for inducing adventitious shoot formation (Lu, 1993). Similar results were also obtained by Sharma and Shahzad (2008) where MS medium supplemented with $0.022 \mu \mathrm{M}$ TDZ proved to be the best for multiple shoot induction from cotyledonary node explants of Abelmoschus moschatus Medik. L. However, Caramori et al. (2001) found the highest number (5.8) of shoots on $0.02 \mu \mathrm{M}$ TDZ in cotton (Gossypium hirsutum L.). Both of these two findings were correlated with the present research, because all of them are from Malvaceae family.

Root formation: Root growth was observed within 2 weeks after the transfer of elongated shoots $(2.0-2.5 \mathrm{~cm})$ to rooting medium. The frequency of rooting on three different concentrations of media was variable (Table 3). The highest rooting percentage (83.3) was recorded in media supplemented with $2.46 \mu \mathrm{M}$ IBA followed by 0.53 NAA (75.0) (Table 3 and Fig 1d) where Rahman et al. (2008) obtained $63.5 \%$ microshoots initiated roots in $1 / 2 \mathrm{MS}+0.5 \mu \mathrm{M}$ IBA medium from hypocotyl explants of okra. Additionally, leaf disc and hypocotyl derived callus of okra produced $50 \%$ and $55 \%$ rooting frequency in $2.46 \mu \mathrm{M}$ IBA, respectively (Kabir et al., 2008). Thus, the present study showed that cotyledonary node explants performed better in rooting of in vitro regenerated okra shoots.

Rooting response variation may be affected by different conditions of shoots used for root induction, variations in the medium used for multiplication before root induction, the number of subcultures before root induction and the culture period on multiplication medium before transfer to root induction medium (Pal et al., 2007). The differences in rooting response may be a result of genotype or cultural conditions. Pathi and Tuteja, (2013) observed root induction between 1015 days on media supplemented with $4.92 \mu \mathrm{M}$ IBA in cotton. In the present research, minimum days (9.7) required for rooting was recorded in media supplemented with $2.46 \mu \mathrm{M}$ IBA following $0.53 \mu \mathrm{M}$ NAA (12.7) where $1 / 2$ strength of MS medium without any growth regulators took more days (16.7) for root induction (Table 3). The healthy rooted plantlets were transferred to greenhouse for hardening (Fig. 1e). After 2-3 weeks the plantlets were transferred to the large pot for further growth (Fig. 1f). 
Table 1. Response of cotyledonary nodes and hypocotyl explants of BARI Dherosh-1 on media having varying concentrations of plant growth regulators

\begin{tabular}{|c|c|c|c|c|c|}
\hline \multirow{2}{*}{\multicolumn{2}{|c|}{$\begin{array}{l}\text { Concentration } \\
\qquad(\mu \mathrm{M})\end{array}$}} & \multicolumn{2}{|c|}{ Cotyledonary node } & \multicolumn{2}{|c|}{ Hypocotyl } \\
\hline & & $\%$ of response & Type of response & $\%$ of response & $\begin{array}{l}\text { Type of } \\
\text { response }\end{array}$ \\
\hline \multicolumn{2}{|c|}{ Control } & 0.0 & NR & 83.3 & $\mathrm{R}$ \\
\hline \multicolumn{6}{|c|}{$2,4-\mathrm{D}$} \\
\hline \multicolumn{2}{|c|}{2.26} & 100.0 & $\mathrm{C}$ & 100.0 & $\mathrm{C}+\mathrm{R}$ \\
\hline \multicolumn{2}{|c|}{4.52} & 94.4 & $\mathrm{C}$ & 100.0 & $\mathrm{C}+\mathrm{R}$ \\
\hline \multicolumn{2}{|c|}{6.78} & 72.2 & $\mathrm{C}$ & 95.0 & $\mathrm{C}+\mathrm{R}$ \\
\hline \multicolumn{2}{|c|}{9.04} & 77.8 & $\mathrm{C}$ & 75.0 & $\mathrm{C}+\mathrm{R}$ \\
\hline \multicolumn{6}{|c|}{ BAP } \\
\hline \multicolumn{2}{|c|}{2.22} & 95.0 & $\mathrm{C}$ & 100.0 & $\mathrm{C}$ \\
\hline \multicolumn{2}{|c|}{4.44} & 95.0 & $\mathrm{C}$ & 100.0 & $\mathrm{C}$ \\
\hline \multicolumn{2}{|c|}{6.66} & 75.0 & $\mathrm{C}$ & 100.0 & $\mathrm{C}$ \\
\hline \multicolumn{2}{|c|}{8.88} & 100.0 & $\mathrm{C}$ & 100.0 & $\mathrm{C}$ \\
\hline \multicolumn{6}{|c|}{ TDZ } \\
\hline \multicolumn{2}{|c|}{0.022} & 100.0 & $\mathrm{C}+\mathrm{Sh}$ & 100.0 & $\mathrm{C}$ \\
\hline \multicolumn{2}{|c|}{0.044} & 100.0 & $\mathrm{C}+\mathrm{Sh}$ & 100.0 & $\mathrm{C}$ \\
\hline \multicolumn{2}{|c|}{0.22} & 100.0 & $\mathrm{C}+\mathrm{Sh}$ & 100.0 & $\mathrm{C}$ \\
\hline \multicolumn{2}{|c|}{0.45} & 100.0 & $\mathrm{C}+\mathrm{Sh}$ & 100.0 & $\mathrm{C}$ \\
\hline \multicolumn{2}{|c|}{2.25} & 100.0 & $\mathrm{C}+\mathrm{Sh}$ & 100.0 & $\mathrm{C}$ \\
\hline \multicolumn{6}{|c|}{ BAP NAA } \\
\hline 4.44 & 0.53 & 100.0 & $\mathrm{C}+\mathrm{R}$ & 100.0 & $\mathrm{C}+\mathrm{R}$ \\
\hline 8.88 & 0.53 & 100.0 & $\mathrm{C}+\mathrm{R}$ & 100.0 & $\mathrm{C}+\mathrm{R}$ \\
\hline \multicolumn{6}{|c|}{ BAP IAA } \\
\hline 4.44 & 0.57 & 50.0 & $\mathrm{C}$ & 0.0 & NR \\
\hline 8.88 & 0.57 & 50.0 & $\mathrm{C}$ & 0.0 & NR \\
\hline \multicolumn{6}{|c|}{ Zeatin IAA } \\
\hline 4.56 & 0.57 & 83.3 & $\mathrm{C}$ & 94.4 & $\mathrm{C}$ \\
\hline 9.12 & 0.57 & 94.4 & $\mathrm{C}$ & 100.0 & $\mathrm{C}$ \\
\hline
\end{tabular}

(S-Shoot, C-Callus, R-Root, C+Sh-Callus with shoots, C+R-Callus with root, NR-No response). 
Table 2. Effect of different concentrations of TDZ on shoot induction from cotyledonary node explants of BARI Dherosh-1

\begin{tabular}{cccc}
\hline $\begin{array}{c}\text { Concentration } \\
(\mu \mathrm{M})\end{array}$ & \% of shooting & $\begin{array}{c}\text { Days required for } \\
\text { shoot initiation }\end{array}$ & $\begin{array}{c}\text { No. of } \\
\text { shoots/explant }\end{array}$ \\
\hline 0.022 & $33.3^{\mathrm{e}}$ & $10.3^{\mathrm{bc}}$ & $4.3^{\mathrm{b}}$ \\
0.044 & $64.0^{\mathrm{a}}$ & $8.4^{\mathrm{d}}$ & $6.8^{\mathrm{a}}$ \\
0.22 & $50.0^{\mathrm{c}}$ & $9.7^{\mathrm{c}}$ & $2.7^{\mathrm{bc}}$ \\
0.45 & $58.3^{\mathrm{b}}$ & $11.5^{\mathrm{a}}$ & $2.8^{\mathrm{bc}}$ \\
2.25 & $41.7^{\mathrm{d}}$ & $10.1^{\mathrm{bc}}$ & $1.9^{\mathrm{c}}$ \\
\hline
\end{tabular}

The data followed by the same letter(s) did not differ significantly at $\mathrm{p}<0.05$.

Table 3. Effect of different concentrations of plant growth regulators on root induction from cotyledonary node explants of BARI Dherosh-1.

\begin{tabular}{ccc}
\hline $\begin{array}{c}\text { Concentration } \\
(\mu \mathrm{M})\end{array}$ & \% of rooting & $\begin{array}{c}\text { Days required for root } \\
\text { initiation }\end{array}$ \\
\hline $1 / 2 \mathrm{MS}$ & $58.3^{\mathrm{c}}$ & $16.7^{\mathrm{a}}$ \\
$2.46 \mathrm{IBA}$ & $83.3^{\mathrm{a}}$ & $9.7^{\mathrm{b}}$ \\
$0.53 \mathrm{NAA}$ & $75.0^{\mathrm{b}}$ & $12.7^{\mathrm{ab}}$ \\
\hline
\end{tabular}

The data showed the same letter(s) do not differ significantly at $\mathrm{p}<0.05$.
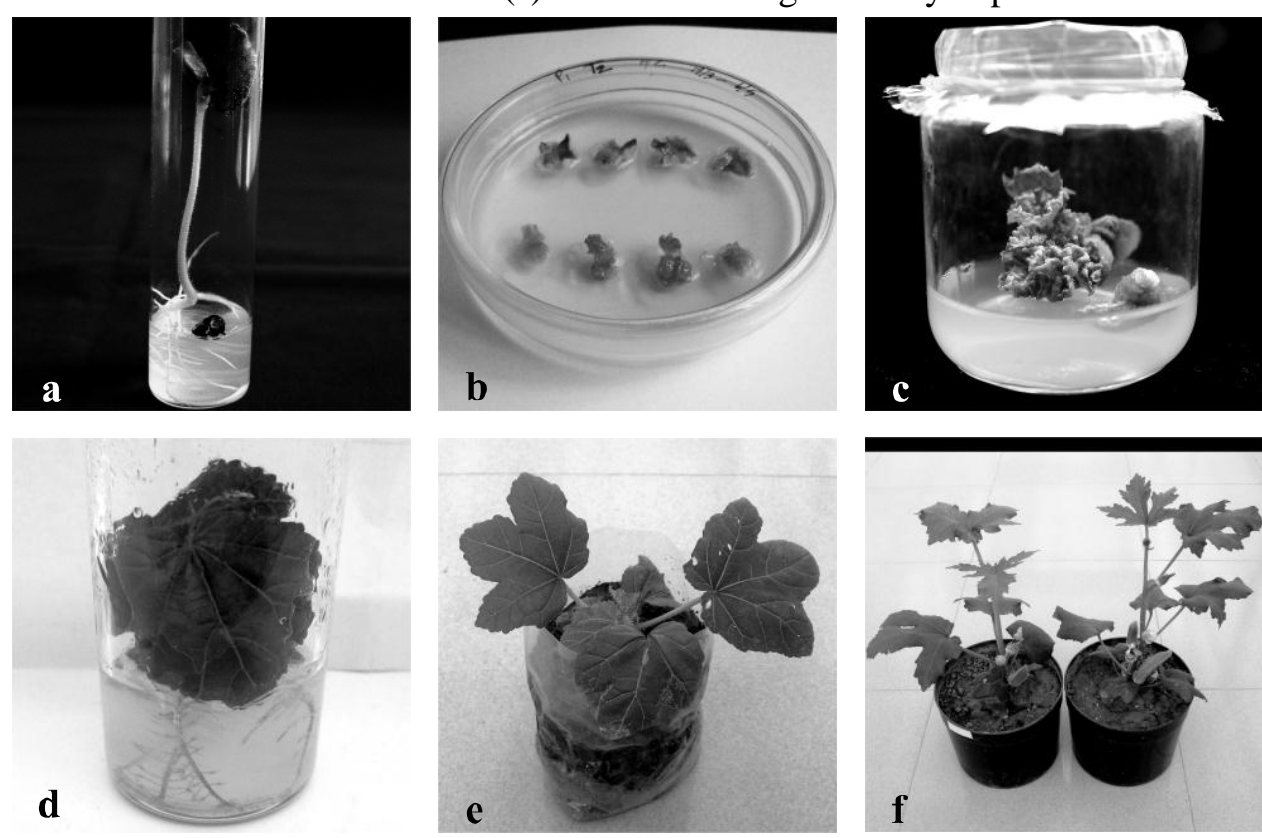

Fig. 1. Regeneration of BARI Dherosh 1. a) 10-12 day's old germinated seedling b) shoot initiation on $0.044 \mu \mathrm{M}$ TDZ c) multiple shoots on $0.044 \mu \mathrm{M}$ TDZ d) rooted shoots on $2.46 \mu \mathrm{M}$ IBA e) hardening of plantlet in green house and f) seedlings with fruits. 


\section{Conclusion}

Development of a highly efficient regeneration protocol based on using cotyledonary nodes as explants for the induction of multiple shoots from 0.044 $\mu \mathrm{M}$ TDZ in okra is described here. The time taken from culture initiation to the establishment of plants in the greenhouse was shorter (about 3 months) as compared with the longer periods reported in previously published regeneration protocols. The important feature of the present protocol is shortening of regeneration time, as well as the induction of high number of multiple shoots per explant. Besides, this stable and reliable regeneration protocol is expected to be helpful for future research on genetic transformation on okra.

\section{References}

Adom, K.K., V.P. Dzogbefia, W.O. Ellis and B.K. Simpson. 1996. Solar drying of okraeffects of selected package materials on storage stability. Food Research International. 29(7): 589-593.

Anisuzzaman, S., S. Jarin, K. Naher, M. M. Akhtar and M.J. Alam. 2008. Callus Induced Organogenesis in Okra (Abelmoschus esculentus L. Moench.). Asian J. Plant Sci. 7(7): 677-681.

Aworh, O.C., A.O. Olorunda and O. Akibo. 1980. Quality attributes of frozen okra as influenced by processing and storage. Journal of Food Technology. 15: 429-433.

BBS. 2015. Year Book of Agricultural Statistics-2013. Statistics and Informatics Division, Ministry of Planning, Dhaka.

Caramori, L.P.C., S. Favaro and L.G.E. Vieira. 2001. Thidiazuron as a promoter of multiple shoots in cotton explants (Gossypium hirsutum L.). Acta Scientiarum. 23(5): 1195-1197.

Dhande, G.A., V.M. Patil, R.V. Raut, J.C. Rajput and A.G. Ingle. 2012. Regeneration of okra (Abelmoschus esculentus L.) via apical shoot meristem. Afr. J. Biotechnol. 11(86): 15226-15230.

Ganesan, M., R. Chandrasekar, B. Kumari, N. Jayabalan. 2007. Somatic embryogenesis and plant regeneration of Abelmoschus esculentus through suspension culture. Biol. Plant. 51(3): 414-420.

Haider, S.A., R. Islam, A.H.M. Kamal, S.M. Rahman and O.I. Joarder. 1993. Direct and indirect organogenesis in cultured hypocotyl explants of Abelmoschus esculentus $\mathrm{L}$. Moench. Plant Tissue Cult. 3(2): 85-89.

Ihekoronye, A.I. and P.O. Ngoddy. 1985. Integrated food science and technology for the tropics. Pp. 205-206, 293.

Kabir, A.H., K.K. Sarker, S.A. Sharmin, M.S. Islam and M.F. Alam. 2008. Callus induction and plantlet regeneration in Abelmoschus esculentus (L.) Moench. Journal of Agricultural Technology. 4(1): 193-204.

Khawar, K.M., C. Saneak, S. Uranbey ans S. Zean. 2004. Effect of thidiazuron on shoot regeneration from different explants of lentil (Lens culinaris Medik.) via oganogenesis. Turk. J. Bot. 28: 421-426. 
Kucharek, T. 2004. Florida plant disease management guide: Okra. Plant Pathology Department document PDMG-V3-41. Florida Cooperative Extension Service, Institute of Food and Agricultural Sciences, University of Florida, Gainesville, FL.

Lu, C. 1993. The Use of Thidiazuron in Tissue Culture. In Vitro Cell. Dev. Biol. 29: 92-96.

Mangat, B.S. and M.K. Roy. 1986. Tissue culture and plant regeneration of okra (Abelmoschus esculentus). Plant. Sci. 47: 57-61.

Mitra, M.B. 2011. Multiple shoot regeneration of cotton (Gossypium hirsutum L.) via shoot apex culture system. Afr. J. Biotechnol. 10(11): 2005-2011.

Mok, M.C., R.C. Martin and D.W.S. Mok. 2000. Cytokinins: Biosynthesis, metabolism and perception. In Vitro Cell Dev. Biol. Plant. 36: 102-107.

Murashige, T. and F. Skoog. 1962. A revised medium for rapid growth and bioassay with tobacco tissue cultures. Physiol. Plant. 15: 473-497.

Pal, S.P., I. Alam, M. Anisuzzaman, k. K. Sarker, S. A. Sharmin and M. F. Alam. 2007. Indirect organogenesis in summer squash (Cucurbita pepo L.). Turkish. J. Agric. For. 31: 63-70.

Pathi, K.M. and N. Tuteja. 2013. High-frequency regeneration via multiple shoot induction of an elite recalcitrant cotton (Gossypium hirsutum L. cv Narashima) by using embryo apex. Plant Signaling \& Behavior. 8(1): e22763-94.

Pullaiah, N., T.B. Reddy, G.J. Moses, B.M. Reddy and D.R. Reddy. 1998. Inheritance of resistance to yellow vein mosaic virus in okra (Abelmoschus esculentus L. Moench). Ind. J. Gene. Plant Breeding. 8(3): 349-352.

Rahman, M.T., M.J. Hossain and M. Khalekuzzaman. 2008. In vitro indirect plantlet regeneration from hypocotyl segments and cotyledonary explant derived calli in lady's finger (Abelmoschus esculentus L. Monech). J. bio-sci. 16: 49-57.

Sharma, R. and A. Shahzad. 2008. Thidiazuron (TDZ) Induced Regeneration from Cotyledonary Node Explant of Abelmoschus moschatus Medik. L., (A Valuable Medicinal Plant). World J. Agric. Sci. 4(4): 449-452. 